\title{
Conservation of $5-\mathrm{HT}_{1 \mathrm{~A}}$ receptor-mediated autoinhibition of serotonin (5-HT) neurons in mice with altered $5-\mathrm{HT}$ homeostasis
}

\author{
Naozumi Araragi ${ }^{1}{ }^{\dagger}$, , Boris Mlinar ${ }^{2}$, Gilda Baccini $^{2}$, Lise Gutknecht ${ }^{3}$, Klaus-Peter Lesch $^{1}$ and \\ Renato Corradetti ${ }^{2}$ \\ ' Division of Molecular Psychiatry, Laboratory of Translational Neuroscience, Department of Psychiatry, Psychosomatics, and Psychotherapy, \\ University of Wuerzburg, Wuerzburg, Germany \\ ${ }^{2}$ Department of NEUROFARBA (Department of Neuroscience, Psychology, Drug Research and Child Health), University of Florence, Florence, Italy \\ ${ }^{3}$ Department of Neurobiology, Institute of Functional Genomics, National Center for Scientific Research (UMR 5203), INSERM U661, \\ University of Montpellier I and II, Montpellier, France
}

\section{Edited by:}

Laurence Lanfumey, Institut National de la Santé et de la Recherche

Médicale, France

Reviewed by:

Heather Hain, PsychoGenics, Inc., USA

Laurence Lanfumey, Institut National de la Santé et de la Recherche Médicale, France

\section{*Correspondence:}

Naozumi Araragi, Division of

Molecular Psychiatry, Laboratory of

Translational Neuroscience,

Department of Psychiatry,

Psychosomatics, and Psychotherapy,

University of Wuerzburg

Fuechsleinstrasse 15, 97080

Wuerzburg, Germany

e-mail: naozumi.araragi@

uni-wuerzburg.de

${ }^{\dagger}$ Present address:

Naozumi Araragi, Experimental Neurosurgery, Department of Neurosurgery, University of

Wuerzburg, Josef-Schneider-Strasse

11, 97080 Wuerzburg, Germany
Firing activity of serotonin (5-HT) neurons in the dorsal raphe nucleus (DRN) is controlled by inhibitory somatodendritic $5-\mathrm{HT}_{1 \mathrm{~A}}$ autoreceptors. This autoinhibitory mechanism is implicated in the etiology of disorders of emotion regulation, such as anxiety disorders and depression, as well as in the mechanism of antidepressant action. Here, we investigated how persistent alterations in brain 5-HT availability affect autoinhibition in two genetically modified mouse models lacking critical mediators of serotonergic transmission: 5-HT transporter knockout (Sert-/-) and tryptophan hydroxylase-2 knockout (Tph2-/-) mice. The degree of autoinhibition was assessed by loose-seal cell-attached recording in DRN slices. First, application of the 5-HT1A-selective agonist $\mathrm{R}(+)-8$-hydroxy-2-(di$\mathrm{n}$-propylamino)tetralin showed mild sensitization and marked desensitization of $5-\mathrm{HT}_{1 \mathrm{~A}}$ receptors in Tph2-/- mice and Sert-/- mice, respectively. While 5-HT neurons from Tph2-/- mice did not display autoinhibition in response to L-tryptophan, autoinhibition of these neurons was unaltered in Sert-/- mice despite marked desensitization of their 5-HT 1 A autoreceptors. When the Tph2-dependent 5-HT synthesis step was bypassed by application of 5-hydroxy-L-tryptophan (5-HTP), neurons from both Tph2-/- and Sert-/mice decreased their firing rates at significantly lower concentrations of 5-HTP compared to wildtype controls. Our findings demonstrate that, as opposed to the prevalent view, sensitivity of somatodendritic $5-\mathrm{HT}_{1 \mathrm{~A}}$ receptors does not predict the magnitude of $5-\mathrm{HT}$ neuron autoinhibition. Changes in $5-\mathrm{HT}_{1 \mathrm{~A}}$ receptor sensitivity may rather be seen as an adaptive mechanism to keep autoinhibition functioning in response to extremely altered levels of extracellular 5-HT resulting from targeted inactivation of mediators of serotonergic signaling.

Keywords: serotonin transporter, tryptophan hydroxylase-2, knockout, dorsal raphe nucleus, autoinhibition, $5-\mathrm{HT}_{1 \mathrm{~A}}$ receptor

\section{INTRODUCTION}

The brain serotonin (5-HT) system has been implicated in emotion regulation and related psychopathological states, including anxiety, depression, impulsivity, and aggression (reviewed in Lesch et al., 2012). The 5-HT system originates from specified neurons located in distinct nuclei of the brainstem raphe complex. Among them, the dorsal raphe nucleus (DRN) contains the majority of 5-HT neurons and sends projections to various targets in the forebrain. 5-HT neurons in the DRN are known to exhibit spontaneous regular firing activities (Trulson and Jacobs, 1979; Vandermaelen and Aghajanian, 1983). The firing rate of 5HT neurons is a determinant of 5-HT concentration and thus

Abbreviations: DRN, dorsal raphe nucleus; 5-HT, serotonin; 5-HTP, 5-hydroxyL-tryptophan; R(+)-8-OH-DPAT, R(+)-8-hydroxy-2-(di-n-propylamino)tetralin; Sert, serotonin transporter; Tph2, tryptophan hydroxylase-2; Trp, L-tryptophan. function in terminal regions, together with local mechanisms (Jacobs and Azmitia, 1992). In waking states, firing of 5-HT neurons is facilitated by noradrenergic input (Levine and Jacobs, 1992). Activity of 5-HT neurons is, in turn, limited by homeostatic negative feedback control exerted by extracellular 5-HT via somatodendritic inhibitory $5-\mathrm{HT}_{1 \mathrm{~A}}$ autoreceptors (Audero et al., 2008 and references therein). The role of 5-HT $\mathrm{HA}_{1 \mathrm{~A}}$ receptors in suppression/regulation of 5-HT neuron firing activity is considered to be relevant to the pathophysiology of disorders of emotion regulation (Pineyro and Blier, 1999; Sharp et al., 2007). The importance of $5-\mathrm{HT}_{1 \mathrm{~A}}$ receptor function is further supported by the presumed mechanism of selective 5-HT reuptake inhibitor (SSRI) antidepressant action (Artigas et al., 1996; Pineyro and Blier, 1999). After acute administration of SSRI, extracellular 5-HT concentrations transiently increase and activate $5-\mathrm{HT}_{1 \mathrm{~A}}$ autoreceptors, inhibiting firing of 5-HT neurons. One criterion 
of antidepressants' therapeutic effects is desensitization of these $5-\mathrm{HT}_{1 \mathrm{~A}}$ receptors, leading to a net increase of 5-HT levels. In this context, dysfunction of autoinhibitory $5-\mathrm{HT}_{1 \mathrm{~A}}$ receptors has been proposed as a potential factor contributing to the pathogenesis of emotional disorders. However, studies on $5-\mathrm{HT}_{1 \mathrm{~A}}$ receptor expression in the raphe nuclei of patients with depression measured in vivo using positron emission tomography (PET) or in post-mortem brains have yielded contradictory findings: some investigators reported decreased expression (Drevets et al., 1999; Sargent et al., 2000; Arango et al., 2001; Meltzer et al., 2004), while others found enhanced expression (Stockmeier et al., 1998) or no difference compared to controls (Parsey et al., 2006). Moreover, PET imaging data revealed reduced $5-\mathrm{HT}_{1 \mathrm{~A}}$ binding in several brain regions including the raphe complex in panic disorder patients either with or without comorbid depression (Neumeister et al., 2004). To date, most studies concentrated on associations between expression levels of $5-\mathrm{HT}_{1 \mathrm{~A}}$ receptors with depressive disorders and there has been no direct evidence demonstrating how altered $5-\mathrm{HT}_{1 \mathrm{~A}}$ receptor availability translates into the extent of 5-HT neuron autoinhibition. The discrepancies among reports describing a relationship between $5-\mathrm{HT}_{1 \mathrm{~A}}$ receptor expression and depression indicate a need for better understanding of the precise mechanisms linking autoinhibition to $5-\mathrm{HT}_{1 \mathrm{~A}}$ receptor function.

Among various mediators of the brain 5-HT signaling, the 5-HT transporter (SERT, 5-HTT, SLC6A4) plays a central role because (i) it mediates the re-uptake of 5-HT from the extracellular space/synapse and thus terminates the 5-HT signaling and (ii) it is the target of numerous antidepressant drugs which inhibit its action. Carriers of the short variant (s-allele) of the transcriptional control region of the gene encoding SERT (5-HTT gene-linked polymorphic region, 5-HTTLPR), which leads to lower expression and thus a lower amount of SERT protein, are known to convey increased risk for emotional disorders in interaction with environmental factors (reviewed in Canli and Lesch, 2007). On the other hand, tryptophan hydroxylase $(\mathrm{TPH})$ is the rate-limiting enzyme of 5-HT synthesis by converting the essential amino acid L-tryptophan ( $\operatorname{Trp}$ ) into 5-hydroxy-L-tryptophan (5-HTP). 5HTP is then transformed into 5 -HT by aromatic L-amino acid decarboxylase (AADC; Carlsson et al., 1972). While the first isoform TPH1 produces 5 -HT in peripheral tissues and the pineal gland, the recently discovered TPH2 isoform is responsible for 5HT synthesis in the brain (Gutknecht et al., 2009). Variation of the gene coding for TPH2 has been associated with personality traits related to emotional regulation (Gutknecht et al., 2007). Moreover, several polymorphisms in $\mathrm{TPH} 2$, which had previously been linked to mood disorders, were shown to lead to reduced expression of TPH2 (reviewed in Jacobsen et al., 2012a). Contribution of 5-HT to the regulation of emotion has been further verified by studies on mice with targeted inactivation of either Sert or Tph2. Indeed, Sert knockout (-/-) mice have been shown to display anxiety- and depression-like behaviors (reviewed in Murphy and Lesch, 2008). Tph2-/- mice have also been reported to have altered behaviors such as increased conditioned fear responses, aggression, depression-like behaviors, and impairment of maternal care (Savelieva et al., 2008; Alenina et al., 2009; Mosienko et al., 2012; for review, see Lesch et al., 2012).
Here, we investigated firing activity of DRN 5-HT neurons in brain slices obtained from Sert-/ - mice and Tph2-1- mice using loose-seal cell-attached recording configuration. Compared to wildtype $(w t)$ controls, Sert-1- mice were shown to have $\sim 6$ - to 10 -fold elevated extracellular 5 -HT concentrations at baseline in several brain regions including the striatum and the frontal cortex, while heterozygous Sert $+/-$ mice were shown to have milder increase, e.g., $\sim 3$-fold in the striatum (Fabre et al., 2000; Mathews et al., 2004; Shen et al., 2004). In contrast, Tph2-/- mice were reported to display an almost complete depletion of brain 5-HT, while Tph $2+/-$ mice showed lower reduction in brain 5 -HT, reaching $20-25 \%$ in the rostral raphe (Gutknecht etal., 2012). Both knockout mice therefore provide useful models to investigate potential modulation of autoinhibition of 5-HT neuron firing as a function of varying degrees of 5-HT availability in the cellular environment. Moreover, since both mouse lines have extensively been investigated as models for emotional disorders, investigating 5-HT neuron autoinhibitory functions in these mice will facilitate detection of potential alterations in autoinhibition related to disorders of emotion regulation.

In order to mimic in vivo 5-HT synthesis in in vitro experimental conditions, we applied 5-HT precursors through superfusion of brain slices under recording. Prior to this, we assessed the function of autoinhibitory $5-\mathrm{HT}_{1 \mathrm{~A}}$ receptors by applying their direct agonist. Feasibility of assessing autoinhibition in in vitro conditions had been established in previous studies (Liu et al., 2005; Mlinar et al., 2005; Evans et al., 2008; Gutknecht et al., 2012).

\section{MATERIALS AND METHODS ANIMALS}

Animal handling followed the European Community guidelines for animal care (DL 116/92, application of the European Communities Council Directive 86/609/EEC) and approved by the local committees. The generation and genotyping procedure of Tph2-/- and Sert-/ - animals were described previously (Bengel et al., 1998; Gutknecht et al., 2008). Animals were housed under a $12 \mathrm{~h}$ light/dark cycle (lights on: 08:00-20:00) at ambient temperature of $22 \pm 1^{\circ} \mathrm{C}$ and a relative humidity of $40-50 \%$. Data from Tph2 wt and Sert wt mice were treated together, since both mouse lines were backcrossed more than 10 generations into a C57BL/6J background and thus considered to have the same genetic background. Data from male and female mice were pooled.

\section{DRUGS}

SR-95531 (gabazine; GABA $_{A}$ receptor antagonist), D-AP5 (NMDA glutamate receptor antagonist), DNQX (AMPA/kainate receptor antagonist) were purchased from Ascent Scientific Ltd (Bristol, UK). N-[2-[4-(2-methoxyphenyl)-1-piperazinyl]ethyl]$\mathrm{N}$-2-pyridinylcyclohexanecarboxamide maleate (WAY-100635 maleate; selective $5-\mathrm{HT}_{1 \mathrm{~A}}$ receptor antagonist), CGP-55845 hydrochloride (selective $\mathrm{GABA}_{\mathrm{B}}$ receptor antagonist), and $\mathrm{R}(+)$ 8-hydroxy-2-(di-n-propylamino)tetralin $(\mathrm{R}(+)$-8-OH-DPAT) were purchased from Tocris Bioscience (Bristol, UK). Strychnine (glycine receptor antagonist), Trp, 5-HTP, and L-phenylephrine were obtained from Sigma-Aldrich S.r.l. (Milan, Italy). 


\section{ELECTROPHYSIOLOGICAL RECORDING}

Methods used follow those reported previously (Gutknecht et al., 2012). Mice (28-80 days old) were anesthetized with isoflurane and decapitated. The brain was immediately removed, dissected in ice-cold gassed $\left(95 \% \mathrm{O}_{2}, 5 \% \mathrm{CO}_{2}\right)$ artificial cerebrospinal fluid (ACSF) containing (in mM): $124 \mathrm{NaCl}, 2.75$ $\mathrm{KCl}, 1.25 \mathrm{NaH}_{2} \mathrm{PO}_{4}, 1.3 \mathrm{MgCl}_{2}, 2 \mathrm{CaCl}_{2}, 26 \mathrm{NaHCO}_{3}$, 11 D-glucose ( $\mathrm{pH} \mathrm{7.4),} \mathrm{and} \mathrm{the} \mathrm{brainstem} \mathrm{was} \mathrm{sliced} \mathrm{coronally}$ into $200 \mu \mathrm{m}$ thick slices with a vibratome (DSK-1000; Dosaka Co. Ltd, Kyoto, Japan) and transferred to a multi-well incubation chamber filled with bubbled ACSF at room temperature. After at least $90 \mathrm{~min}$ of recovery, the slices were individually transferred into the recording chamber and superfused continuously with gassed, warmed $\operatorname{ACSF}\left(34-35^{\circ} \mathrm{C}\right)$ at a rate of $2 \mathrm{ml} \mathrm{min}^{-1}$. Superfusing ACSF was supplemented with $10 \mu \mathrm{M}$ phenylephrine to facilitate firing (Vandermaelen and Aghajanian, 1983) and with a mixture of neurotransmitter blockers for glutamate, glycine, and GABA receptors (in $\mu \mathrm{M}$ : 10 DNQX; 20 D-AP5; 10 strychnine; 1 CGP-55845; 10 SR-95531) to functionally isolate the recorded neuron from synaptic input. Neurons were visualized by infrared differential interference contrast video microscopy with a Newicon C2400-07 camera (Hamamatsu, Hamamatsu City, Japan) mounted to an Axioskop microscope (Zeiss, Göttingen, Germany). Recordings were made using an EPC-10 amplifier (HEKA Elektronik, Lambrecht, Germany). Patch pipettes were prepared from thick-walled borosilicate glass on a P-97 BrownFlaming electrode puller (Sutter Instruments, Novato, CA, USA) and had resistance of 3-6 M $\Omega$ when filled with solution containing (in $\mathrm{mM}$ ): $125 \mathrm{NaCl}, 10$ HEPES, $2.75 \mathrm{KCl}, 2 \mathrm{CaCl}_{2}, 1.3$ $\mathrm{MgCl}_{2}$ (pH 7.4 with $\mathrm{NaOH}$ ). Loose-seal cell-attached recordings (5-20 M $\Omega$ seal resistance) were acquired continuously in the voltage-clamp mode. Signals were filtered at $3 \mathrm{kHz}$ and digitized at $10 \mathrm{kHz}$. Pipette potential was maintained at $0 \mathrm{mV}$. Recordings were aborted if firing rate was sensitive to changes in pipette holding potential or if shapes of action current changed. Data were analyzed using Clampfit 9.2 (Molecular Devices, Sunnyvale, CA, USA).

Neurons with likely serotonergic specification were first targeted according to morphological criteria (Brown et al., 2008): 5-HT neurons are clustered along the midline of the DRN and they have a larger soma ( $\sim 20-25 \mu \mathrm{m}$ long-axis diameter) than nonserotonergic neurons $(\sim 10-15 \mu \mathrm{m})$. Once loose-seal cell-attached recording configuration was established, 5-HT neurons were identified according to electrophysiological criteria (Vandermaelen and Aghajanian, 1983; Allers and Sharp, 2003). Neurons were considered serotonergic if, during at least 5 min-long baseline period at the beginning of the recording displayed slow and steady firing rate $(<5 \mathrm{~Hz})$; asymmetric action current with long upstroke to downstroke interval (proportional to action potential half-height width, $>0.85 \mathrm{~ms}$ ). According to these criteria, 250 out of 277 recorded neurons were identified as being serotonergic. Pharmacological experiments were done on 176 presumed serotonergic neurons, whose identity was pharmacologically confirmed based on $5-\mathrm{HT}_{1 \mathrm{~A}}$ receptor-mediated suppression of their firing rate. For all groups of neurons used in pharmacological experiments (Figures 2-4), the basal firing rate was matched and proved to be not different after post hoc statistical analysis (Kruskal-Wallis test, $p>0.7$ ).
Since experiments to assess autoinhibition depend on endogenous 5 -HT, recordings were made from neurons located at least $50 \mu \mathrm{m}$ below the slice surface (Mlinar et al., 2005). A single experiment was done in each slice.

For creating concentration-response curves for $\mathrm{R}(+)-8-\mathrm{OH}-$ DPAT and 5-HTP application, drugs were applied for $10 \mathrm{~min}$ and mean firing rates were calculated from the last 1-min segment of each experimental epoch [e.g., baseline, $\mathrm{R}(+)-8-\mathrm{OH}-\mathrm{DPAT}$ $0.1 \mathrm{nM}, 0.3 \mathrm{nM}$, etc.]. Trp was applied for $15 \mathrm{~min}$ and mean firing rates were obtained from the last 3-min segment of baseline and Trp application.

\section{STATISTICAL ANALYSIS}

All the statistical tests were performed by GraphPad Prism version 5.04 (GraphPad Software, San Diego, CA, USA). First, normality of data distribution was tested by D'Agostino-Pearson omnibus normality test. When the data were normally distributed, genotype effects were tested by one-way ANOVA [expressed as $F_{(\mathrm{df1}, \mathrm{df} 2)}$ values] followed by Tukey's post hoc test. If not, data were analyzed by Kruskal-Wallis test [expressed as $H_{(\mathrm{df})}$ values] with Dunn's post hoc test. For testing effects of Trp in comparison to respective baseline, data (\% change in firing rates) were analyzed by Wilcoxon signed rank test (two-tailed). In all cases, $p<0.05$ was considered statistically significant.

\section{RESULTS}

\section{COMPARISON OF BASAL FIRING RATES ACROSS GENOTYPES}

In the absence of precursor supplementation (Trp or 5-HTP), and in the presence of receptor blockers for glutamate, GABA, and glycine receptors, the basal firing of 5-HT neurons in slices is relieved from the autoinhibitory control of endogenous 5-HT (Mlinar et al., 2005) and local action of major neurotransmitters. In these conditions of pharmacological isolation, the basal firing activity of 5-HT neurons reflects their intrinsic pacemaker activity, a characteristic that is difficult to study in vivo, where the firing activity is under control of both autoinhibition and synaptic input.

We compared the basal firing rates recorded before 5-HT precursor or $5-\mathrm{HT}_{1 \mathrm{~A}}$ receptor agonist application, across genotypes (Figure 1). Overall, 5-HT neurons showed typical regular pacemaker activity and firing rates similar to $w t$ controls [in Hz: Tph2-l-, $1.61 \pm 0.82(n=54) ;$ Tph $2+/-, 1.90 \pm 0.66$ $(n=45) ; w t, 1.97 \pm 0.69(n=54) ;$ Sert $+/-, 1.85 \pm 0.74$ $(n=47)$; Sert-l-, $2.12 \pm 0.75(n=50)$; mean \pm SD; $n=$ number of recorded neurons], except for Tph2-1- in which the firing rate was slightly, but significantly slower than in $w t$ controls ( $p<0.05$, Kruskal-Wallis test followed by Dunn's multiple comparison test). These data show that basic electrophysiological properties underlying the typical pacemaker activity of 5-HT neurons are maintained regardless of genetic inactivation of Tph2 or Sert.

\section{COMPARISON OF 5-HT 1 A RECEPTOR SENSITIVITY ACROSS GENOTYPES}

Since 5 -HT neuron autoinhibition is mediated by $5-\mathrm{HT}_{1 \mathrm{~A}}$ receptors, we investigated the functional response of 5-HT neurons to the $5-\mathrm{HT}_{1 \mathrm{~A}}$ receptor agonist $\mathrm{R}(+)-8-\mathrm{OH}-\mathrm{DPAT}$ in different genotypes. Figure 2 illustrates typical experiments in which increasing 


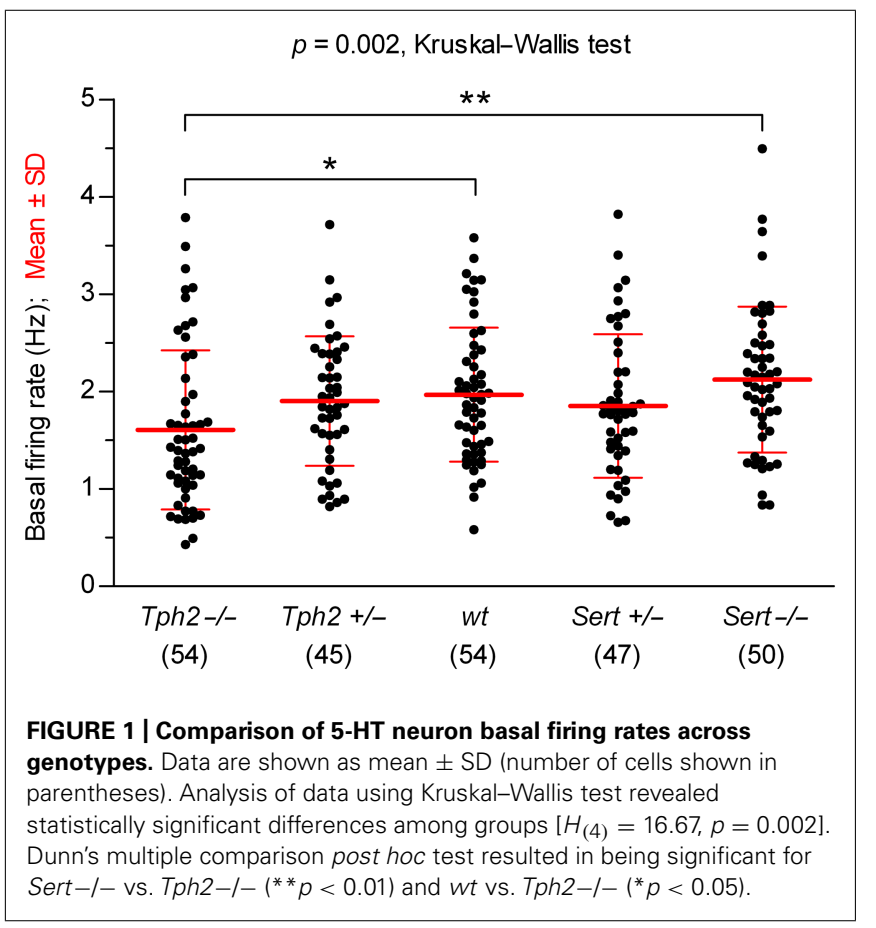

concentrations of $\mathrm{R}(+)-8-\mathrm{OH}-\mathrm{DPAT}$ were applied in slices from $w t$ controls (Figures 2A,B), Tph2-/- (Figures 2C,D), and Sert-/- mice (Figures 2E,F). Application of R(+)-8-OH-DPAT reduced the firing rate of 5-HT neurons in a concentrationdependent manner, but with different effectiveness across genotypes, as shown by the comparison of $\log \mathrm{EC}_{50}$ values obtained for each single neuron tested ( $\log \mathrm{EC}_{50}$ mean $\left.\pm \mathrm{SD}\right)$ : Tph2-/-, $-8.82 \pm 0.29(n=16) ; T p h 2+/-,-8.52 \pm 0.19(n=11) ; w t$, $-8.52 \pm 0.25(n=12)$; Sert $+/-,-8.22 \pm 0.27(n=11)$; Sert-/-, $-7.17 \pm 0.42(n=8$; Figure $2 \mathrm{G})$. Differences across genotypes were statistically significant $\left[F_{(4,53)}=48.38, p<0.0001\right.$, one-way ANOVA]. Compared to $w t$ controls, the response to application of $\mathrm{R}(+)-8-\mathrm{OH}-\mathrm{DPAT}$ resulted in slightly higher effectiveness of the agonist in Tph2-/ - mice $(p<0.05)$ and very weak effectiveness in Sert $-/-$ mice $(p<0.001)$. Although a small decrease in the sensitivity of 5-HT neurons was present also in Sert+/- mice, no statistically significant differences in $\log \mathrm{EC}_{50}$ values were found for both Tph $2+1-$ and Sert+1- vs. wt control mice, indicating that limited impairment of 5-HT synthesis and re-uptake did not result in relevant changes of $5-\mathrm{HT}_{1 \mathrm{~A}}$ autoreceptor sensitivity to $\mathrm{R}(+)-8-\mathrm{OH}-\mathrm{DPAT}$. Figure $\mathbf{2} \mathbf{H}$ shows concentration-response curves fitted for each group on mean data obtained from the individual experiments shown in Figure 2G. It should be noted that in Sert-/- neurons, R(+)-8-OH-DPAT did not produce maximal inhibition of firing (see Figure 2E). Nevertheless, the average maximal inhibition was $60 \%$ compared to the other genotypes and the mean log value of concentrations producing an actual $50 \%$ decrease in firing of Sert-/- neurons was $-6.91 \pm 0.08$ $(n=8)$, which did not affect the level of significance for decreased sensitivity of $5-\mathrm{HT}_{1 \mathrm{~A}}$ receptors shown in Figure 2G. Collectively, these data show that the sensitivity of $5-\mathrm{HT}_{1 \mathrm{~A}}$ receptors to agonist activation is markedly affected in Sert-/-.

\section{ESTIMATION OF AUTOINHIBITION EXERTED BY ENDOGENOUS 5-HT} ACROSS GENOTYPES

After assessing responsiveness to direct activation by the $5-\mathrm{HT}_{1 \mathrm{~A}}$ receptor agonist $\mathrm{R}(+)-8-\mathrm{OH}-\mathrm{DPAT}$ in the different genotypes, we investigated how specific genetic alterations translate into inhibition of 5-HT neuron activity by endogenous 5-HT. Once synthesis of 5-HT is restored in slices by supplementation of 5-HT precursors, the extent of autoinhibition in the different genotypes will depend on the balance between the level of extracellular 5-HT determined by the alteration of homeostatic mechanisms introduced by genetic manipulation and $5-\mathrm{HT}_{1 \mathrm{~A}}$ receptor sensitivity characteristic of each genotype.

Thus, we studied autoinhibition exerted by endogenous 5-HT, when de novo synthesis was restored in slices by supplementation of Trp or 5-HTP. Trp was used to estimate the extent of autoinhibition in respect to bioavailability of the natural precursor (Mlinar et al., 2005). 5-HTP was used to bypass the constraint in 5-HT synthesis produced by the rate-limiting enzyme Tph2. This allows reaching extracellular 5-HT concentrations greater than with Trp and permits quantification of the overall capacity of 5-HT neuron autoinhibition in different genotypes, including Tph2-1- mice.

Figure $3 \mathbf{A}$ shows that supplementation of $\operatorname{Trp}(30 \mu \mathrm{M})$ produced a decrease in firing rates of Sert-/-5-HT neurons, an effect fully antagonized by WAY-100635, a selective $5-\mathrm{HT}_{1 \mathrm{~A}}$ receptor neutral antagonist (Corradetti et al., 1998). This demonstrates that $5-\mathrm{HT}_{1 \mathrm{~A}}$ receptor-mediated autoinhibition is present in Sert-/mice. As shown in Figure 3B, $30 \mu \mathrm{M}$ Trp significantly decreased firing rates of 5-HT neurons to a similar extent in all the genotypes tested (in \% \pm SD): Tph $2+/-, 25.62 \pm 15.37(n=10)$; $w t, 25.55 \pm 19.87(n=7)$; Sert $+/-, 17.51 \pm 12.99(n=11)$; Sert-/-, $22.03 \pm 17.00(n=14)$. In all cases, the decrease in firing rates was significantly different from zero $(p<0.05$; Wilcoxon signed rank test). Furthermore, responses to application of Trp were not statistically different across four genotypes $\left[\mathrm{H}_{(3)}=3.336\right.$, $p=0.3427$; Kruskal-Wallis test $]$. These data show that autoinhibition of DRN 5-HT neurons by endogenous 5-HT is conserved in all the genotypes to a similar level, irrespective of the genetic alteration.

To quantify the extent to which each genotype conserved the capacity to (auto)inhibit 5-HT neuron firing in response to different extracellular concentrations of endogenous 5-HT, we investigated the functional response of 5-HT neurons to 5-HTP in different genotypes.

Figure 4 illustrates firing rate changes of 5-HT neurons in response to increasing concentrations of 5-HTP in brain slices obtained from $w t$ controls (Figures 4A,B), Tph2-I(Figures 4C,D), and Sert-/- mice (Figures 4E-H). Application of 5-HTP reduced the firing rate of 5-HT neurons in a concentration-dependent manner, but with different effectiveness across genotypes [one-way ANOVA, $F_{(4,58)}=6.723, p=0.0002$ ], as shown by the comparison of $\log \mathrm{EC}_{50}$ values obtained for each single neuron tested $\left(\log \mathrm{EC}_{50}\right.$ mean $\left.\pm \mathrm{SD}\right)$ : Tph2-/-, $-5.51 \pm 0.41(n=15) ;$ Tph $2+/-,-5.29 \pm 0.30(n=10)$; $w t,-5.17 \pm 0.20(n=14) ; \operatorname{Sert}+/-,-5.48 \pm 0.36(n=13)$; Sert-/-, $-5.76 \pm 0.12(n=11$; Figure 4I). Interestingly, the sensitivity to the effects of endogenous 5-HT synthesized 

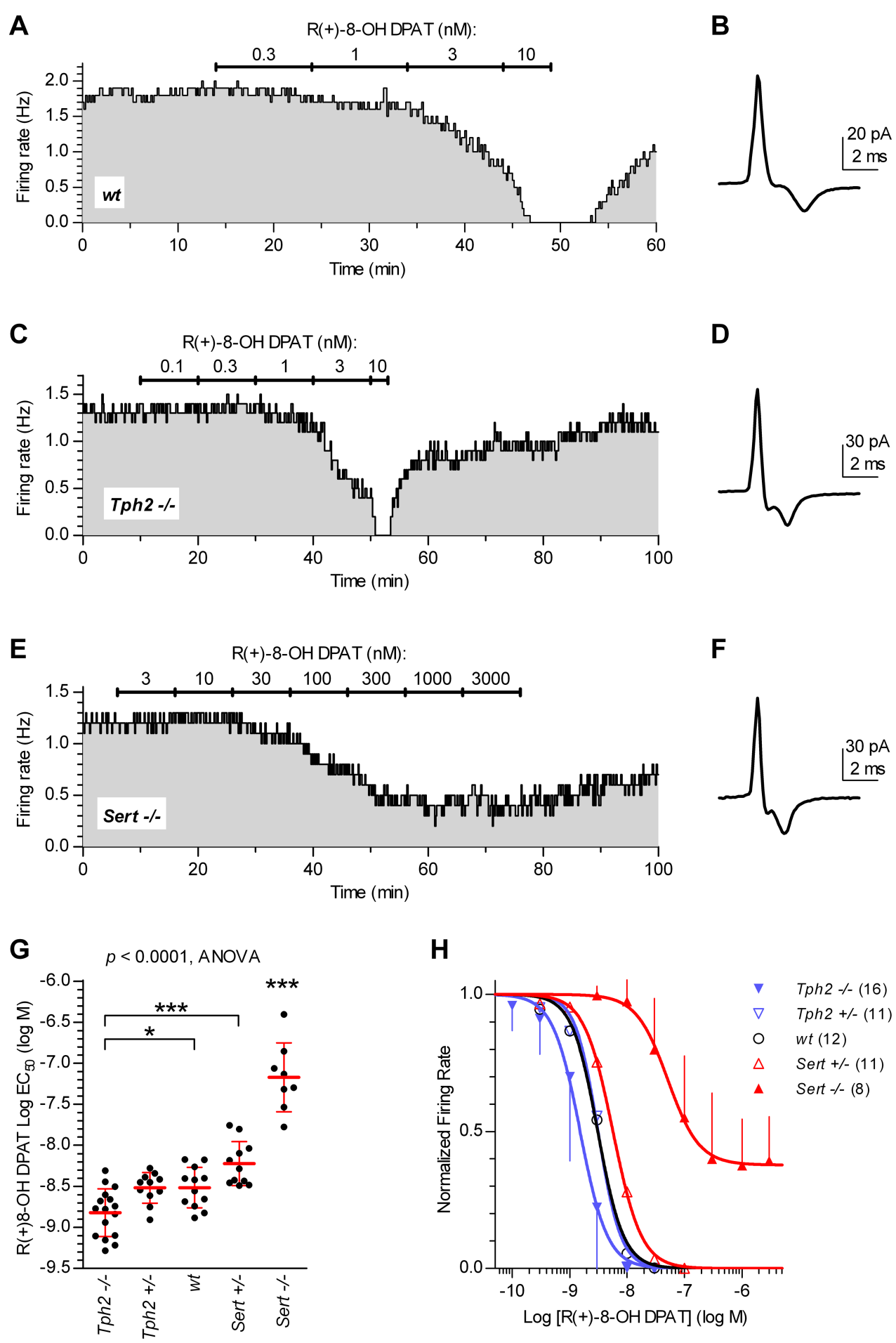

FIGURE 2 | Sensitivity of 5-HT neurons to R(+)-8-OH-DPAT differs across genotypes. Time courses of firing rate changes in response to increasing concentrations of $\mathrm{R}(+)-8-\mathrm{OH}-\mathrm{DPAT}$ of individual $5-\mathrm{HT}$ neurons in brain slices obtained from wt (A,B), Tph2-/- (C,D), and Sert-/- mice $(\mathbf{E}, \mathbf{F})$. Traces show action current of corresponding neurons recorded. (G) Dots represent $\log \mathrm{EC}_{50}$ of concentration-responses from individual experiments. Red lines report mean \pm SD of values. One-way ANOVA followed by Tukey's multiple comparison test showed statistically significant differences across genotypes $\left[F_{(4,53)}=48.38, p<0.0001\right]$.
H

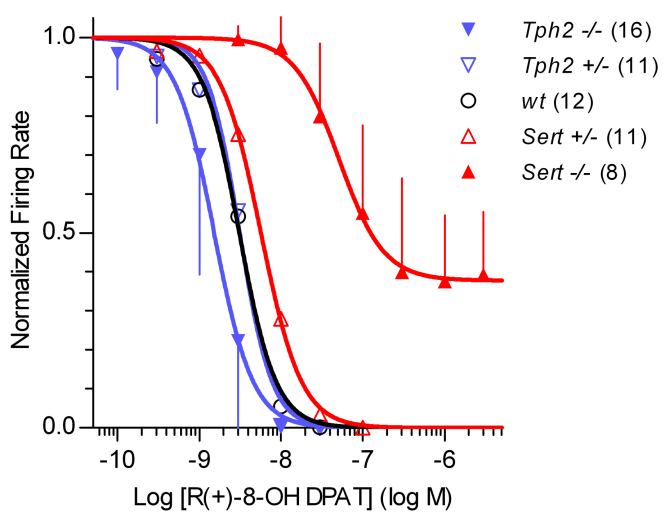

Asterisks indicate level of statistical significance between the indicated genotypes (for Sert-l-, vs. all the other four genotypes): ${ }^{* *} p<0.001$, ${ }^{*} p<0.05$. (H) Average concentration-response curves obtained from all the experiments. Each data point corresponds to the mean from several neurons (numbers in parentheses). For the sake of clarity, error bars are shown only for Sert-/- mice and Tph2-/- mice in a single direction. Data are normalized on average baseline firing rates recorded before $\mathrm{R}(+)-8-\mathrm{OH}-\mathrm{DPAT}$ application. Note that, curves for Sert-/- mice did not achieve full inhibition of firing (see $\mathbf{E})$. 

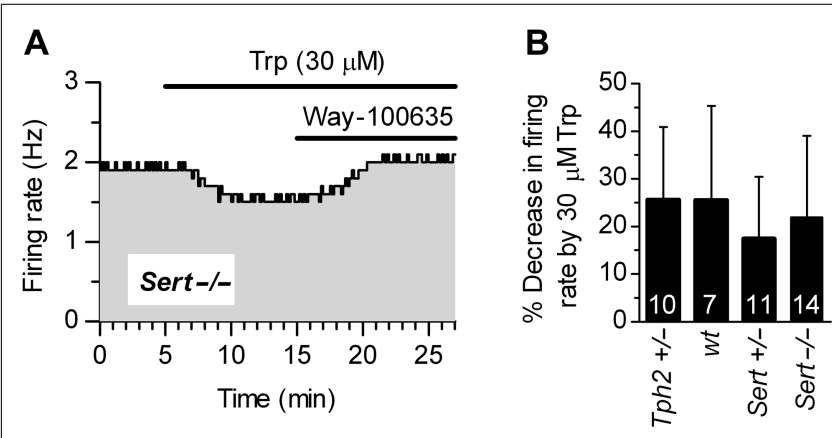

FIGURE 3 | Autoinhibition by endogenous 5-HT synthesized from Trp is conserved across genotypes. (A) $\operatorname{Trp}(30 \mu \mathrm{M})$ produced a $5-\mathrm{HT}_{1} \mathrm{~A}$ receptor-mediated decrease in the firing rate of a $5-\mathrm{HT}$ neuron from Sert-1- mice. Application of a selective 5- $\mathrm{HT}_{1 \mathrm{~A}}$ receptor antagonist, WAY-100635 (50 nM; representative of three experiments) fully antagonized Trp effect, confirming that autoinhibition was mediated by $5-\mathrm{HT}_{1} \mathrm{~A}$ autoreceptors. (B) Application of $30 \mu \mathrm{M}$ Trp significantly suppressed firing activity of DRN serotonergic neurons in all the genotypes tested $(p<0.05$; Wilcoxon signed rank test). Comparison of the effect of Trp among genotypes revealed no statistically significant differences among genotypes $\left[H_{(3)}=3.336, p=0.3427\right.$; Kruskal-Wallis test $]$. Data are shown as mean $\pm S D$. The number of neurons recorded for each genotype is shown at the bottom of the histograms.

from 5-HTP was increased both in Tph2-/- $(p<0.05)$ and Sert-l- $(p<0.001)$ mice compared to $w t$ controls. Figure 4J shows concentration-response curves fitted for each group on mean data obtained from the individual experiments depicted in Figure 4I.

Whereas a stronger autoinhibitory response to 5-HTP in Tph2-1- mice is consistent with the observed increase in sensitivity of $5-\mathrm{HT}_{1 \mathrm{~A}}$ receptors to agonist activation, a similar increase in Sert-I- mice is unexpected in the presence of decreased sensitivity to $\mathrm{R}(+)-8-\mathrm{OH}-\mathrm{DPAT}$. We suggest that, due to the absence of 5-HT re-uptake, in Sert-/- mice the extracellular 5-HT neosynthesized from 5-HTP attains higher levels than in $w t$ control mice, leading to this apparent increase in response. Collectively, these results demonstrate that the changes in sensitivity to direct activation of $5-\mathrm{HT}_{1 \mathrm{~A}}$ receptors cannot directly be translated into the expected changes in autoinhibition exerted by endogenous 5-HT.

\section{DISCUSSION}

In the present study, we have investigated the relationship between the sensitivity of $5-\mathrm{HT}_{1 \mathrm{~A}}$ receptors and the concomitant degree of autoinhibition of 5-HT neurons in a panel of genetically modified mice characterized by impairment of cellular mechanisms crucial for homeostatic control of extracellular 5-HT levels (i.e., 5-HT synthesis and 5-HT re-uptake). In vivo, these genetic manipulations are likely to produce lifelong persistent modifications of 5-HT levels ranging from the absence of 5-HT in Tph2-/mice (Savelieva et al., 2008; Alenina et al., 2009; Gutknecht et al., 2012) to a substantial increase in extracellular 5-HT levels in Sert-/- mice (Fabre et al., 2000; Mathews et al., 2004; Shen et al., 2004). The consequences of genetic alterations are maintained in vitro. This provides a set of conditions in which the relationship between the sensitivity of $5-\mathrm{HT}_{1 \mathrm{~A}}$ receptors and the autoinhibitory response of 5-HT neurons exerted by endogenous 5-HT could be quantitatively compared.

The major finding of the present study is that substantial and persistent alterations in 5-HT homeostasis produced changes in the sensitivity of $5-\mathrm{HT}_{1 \mathrm{~A}}$ receptors that did not translate in measurable changes of autoinhibitory regulation of 5-HT neuron firing. In particular, Sert-1- mice showed a marked subsensitivity of $5-\mathrm{HT}_{1 \mathrm{~A}}$ receptors, but displayed a normal capacity of autoinhibition. Interestingly, the sensitivity of $5-\mathrm{HT}_{1 \mathrm{~A}}$ receptors of both Sert $+1-$ and Tph $2+1-$ mice proved to be similar to that of $w t$ control mice, showing that mild change in extracellular 5-HT levels is neither a strong stimulus for $5-\mathrm{HT}_{1 \mathrm{~A}}$ receptor adaptive changes in sensitivity, nor does it detectably affect autoinhibition.

In previous studies under similar recording conditions as used in this work, raphe slices showed substantial depletion of 5-HT in the absence of 5-HT precursors (Liu etal., 2005; Mlinar etal., 2005). In vitro, 5-HT content, together with $5-\mathrm{HT}_{1 \mathrm{~A}}$ receptor-mediated autoinhibition, can be restored by supplementation of Trp (Liu etal., 2005; Mlinar et al., 2005; Evans etal., 2008; Gutknecht etal., 2012). This allowed electrophysiological, quantitative, assessment of the modifications in sensitivity of $5-\mathrm{HT}_{1 \mathrm{~A}}$ receptors produced by altered $5-\mathrm{HT}$ homeostasis in vivo and estimation of the functional state of autoinhibition when de novo synthesis of 5-HT was restored in slices.

\section{GENETIC MANIPULATIONS DO NOT AFFECT PACEMAKER CHARACTERISTICS OF 5-HT NEURONS}

The pacemaker properties of serotonergic neurons measured in slices in the virtual absence of endogenous 5-HT neosynthesis, hence of autoinhibition, were not substantially altered by genetic manipulation itself, as we observed similar baseline firing rates among genotypes, except for Tph2-/- mice, which had slightly lower baseline firing rates compared to the other genotypes. This shows that the basic characteristics of intrinsic pacemaker firing activity of 5-HT neurons are preserved independently from genetic manipulations that altered 5-HT homeostatic regulation. The small decrease in baseline firing rates observed in Tph2-1mice may indicate that, in the chronic absence of 5-HT, neurons adapt their membrane properties, e.g., conductance, to compensate for absent autoinhibition and homeostatically keep pacemaker firing activity constant. The mechanism(s) underlying this adaptation is currently under investigation. It should be noted that the basal firing rate recorded under our experimental conditions, i.e., in vitro, results from the interplay of ion conductances responsible for pacemaking activity and likely do not correspond to the "basal" firing rate recorded in vivo (e.g., Gobbi et al., 2001; Bouali et al., 2003; see below) which is under the control of $5-\mathrm{HT}_{1 \mathrm{~A}}$ receptormediated autoinhibition in all genotypes (see Figure 3), except in Tph2-/- mice (Gutknecht et al., 2012).

\section{LIFELONG EXPOSURE OF 5-HT NEURONS TO VARYING 5-HT LEVELS RESULTS IN CHANGES IN THE SENSITIVITY OF SOMATODENDRITIC 5-HT ${ }_{1 A}$ RECEPTORS}

Previous studies showed adaptive decrease in sensitivity of $5-\mathrm{HT}_{1 \mathrm{~A}}$ receptors in Sert-/- mice (Lanfumey et al., 2000; Mannoury 

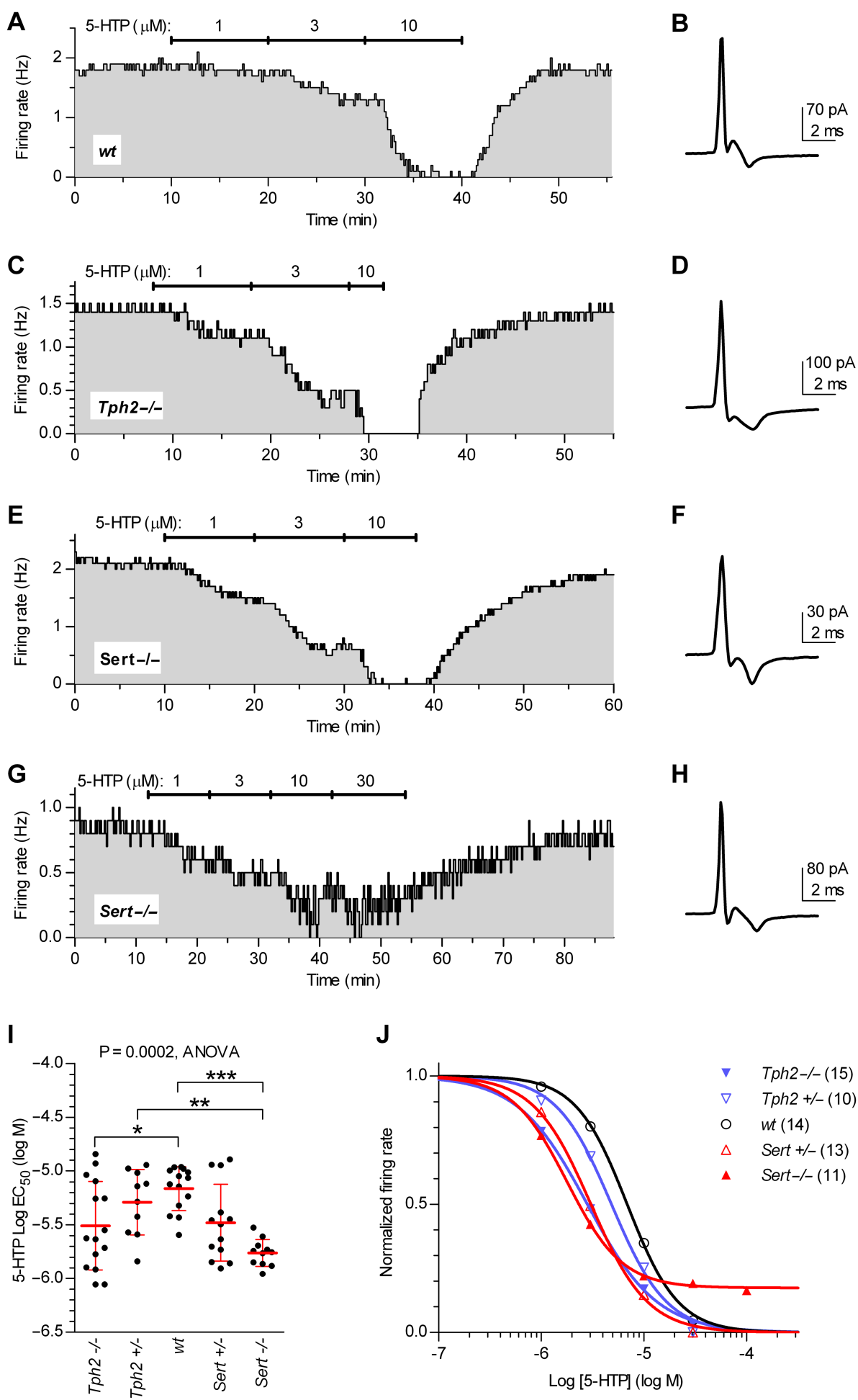

FIGURE 4 | Quantification of autoinhibition capacity of 5-HT neurons across genotypes by concentration-response curves for 5-HTP. Time courses of 5-HT neuron firing rate changes in response to increasing concentrations of 5-HTP in brain slices obtained from $w t$ controls (A,B), Tph2-/- (C,D), and Sert-/- mice (E-H). Traces show action current of corresponding neurons recorded. (I) Dots represent log $\mathrm{EC}_{50}$ of concentration-responses from individual experiments. Red lines report mean \pm SD of values. One-way ANOVA followed by Tukey's multiple

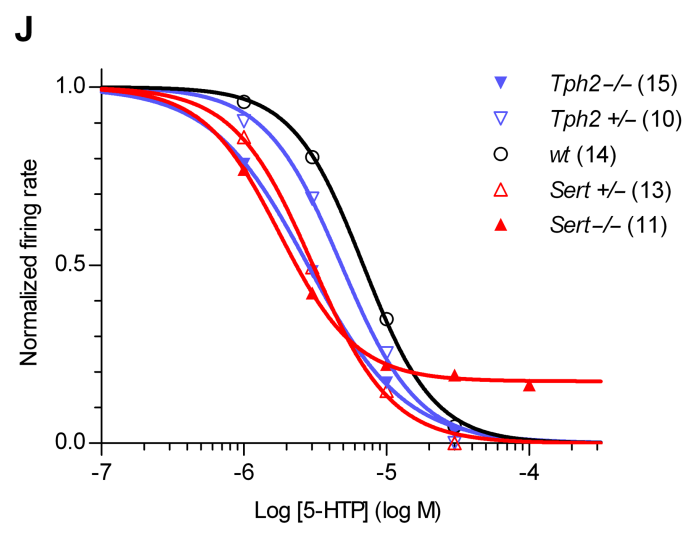

comparison test showed statistically significant differences $\left[F_{(4,58)}=6.723\right.$, $p=0.0002$ ] Asterisks indicate level of statistical significance between the indicated genotypes: ${ }^{* *} p<0.001,{ }^{*} p<0.01,{ }^{*} p<0.05$. (J) Average concentration-response curves obtained from all the experiments. Each data point corresponds to the mean from several neurons (numbers shown in parentheses). For the sake of clarity, error bars are omitted. Data are normalized on average baseline firing rates recorded before 5-HTP application. 
la Cour et al., 2001; Bouali etal., 2003). Our study extends the investigation to the opposite extreme, i.e., Tph2-/- mice, which are devoid of 5-HT and show a small, but significant increase in $5-\mathrm{HT}_{1 \mathrm{~A}}$ receptor sensitivity. This is consistent with neurochemical data showing an increase in $5-\mathrm{HT}_{1 \mathrm{~A}}$ receptor density in the raphe (Gutknecht et al., 2012).

In Sert-1- mice, we found a decrease in the maximal response to $\mathrm{R}(+)-8$-OH-DPAT $(\sim 40 \%)$ and a similar reduction of autoinhibitory capacity as revealed by concentration-response curves with 5-HTP. This may reflect a downregulation of $5-\mathrm{HT}_{1 \mathrm{~A}}$ receptors due to lifelong exposure to increased stimulation by 5 -HT or the emergence of a still-unknown adaptive mechanism directed to counteract increased autoinhibition exerted by high levels of extracellular 5-HT in vivo. In spite of the decrease, however, the remaining autoinhibition capacity of 5-HT neurons largely exceeded the magnitude of physiological autoinhibition produced by 5 -HT when its synthesis was restored by $\operatorname{Trp}$ (see below).

Taken together, our data indicate that the level of $5-\mathrm{HT}_{1 \mathrm{~A}}$ receptor sensitivity of 5-HT neurons is inversely correlated with extracellular levels of 5-HT in vivo, at least in extreme conditions as represented by Tph2-I- and Sert-I- mice.

\section{AUTOINHIBITION OF 5-HT NEURONS BY ENDOGENOUS 5-HT IS CONSERVED IN THE PHYSIOLOGICAL RANGE, REGARDLESS OF THE SENSITIVITY OF 5-HT 1 A RECEPTORS}

When the level of autoinhibition restored by Trp supplementation in slices from all the genotypes (except Tph2-/-) was measured, this resulted in being similar, irrespective of the sensitivity of $5-\mathrm{HT}_{1 \mathrm{~A}}$ receptors measured in each genotype. Notably, Sert-/- showed greatly decreased sensitivity to the agonist but normal autoinhibition, as estimated by Trp challenge. Accordingly, the autoinhibitory effect of endogenous 5-HT synthesized de novo from 5-HTP proved to be not decreased in all the mutants compared with wt controls, including Tph2-1- in which the absence of Tph2 was bypassed by 5 -HTP. It should be noted that in Sert-I- mice the maximal inhibitory response was slightly decreased $(\sim 20 \%)$ in agreement with the reduced maximal response to the agonist, but the substantial residual inhibition capacity is apparently sufficient to produce a physiological level of autoinhibition as shown by Trp experiments. In conclusion, these data indicate that the marked subsensitivity of $5-\mathrm{HT}_{1 \mathrm{~A}}$ receptors observed in Sert-/- does not translate in the loss of normal autoinhibition capacity of 5-HT neurons.

Although counterintuitive, this notion is consistent with the observation that, in vivo, the firing rate of 5-HT neurons is not increased in Sert-/-, but similar to or even lower (Gobbi et al., 2001; Bouali et al., 2003) than that of $w t$ controls, thus indicating that in vivo subsensitivity of $5-\mathrm{HT}_{1 \mathrm{~A}}$ receptors in Sert-/- mice does not relieve 5-HT neurons from autoinhibition. Furthermore, Fox et al. (2010) reported that in these mice antagonism of 5-HT $1 \mathrm{~A}$ receptors by WAY-100635 resulted in the appearance of greater frequency of $5-\mathrm{HT}_{2 \mathrm{~A}}$ receptor-mediated head twitches than in $w t$ controls. This suggests that the relief from autoinhibition, hence the increase in 5-HT neuron firing, produces an increase in 5$\mathrm{HT}$ release sufficient to produce this $5-\mathrm{HT}_{2 \mathrm{~A}}$-mediated behavioral effect (Willins and Meltzer, 1997), even in the presence of partial desensitization of 5- $\mathrm{HT}_{2 \mathrm{~A}}$ receptors (Rioux et al., 1999; Li et al., 2003; Qu et al., 2005).

\section{IMPLICATIONS OF THE DIVERGENCE BETWEEN SENSITIVITY TO R(+)-8-0H-DPAT AND 5-HT NEURON AUTOINHIBITION}

The crucial role of somatodendritic $5-\mathrm{HT}_{1 \mathrm{~A}}$ receptors in regulating the firing rate of 5-HT neurons, hence the functional state of 5 -HT system, has attracted interest in the attempt to infer the degree of activity of these neurons in pathological conditions of humans and in behavioral experiments of rodents. The present work may help to better understand the limits in the interpretation of the functional state of 5-HT system based on measurements of density/sensitivity of $5-\mathrm{HT}_{1 \mathrm{~A}}$ receptors of $5-\mathrm{HT}$ neurons. Furthermore, since the knockout mice used in this investigation may model different risk factors (i.e., TPH2 and SERT polymorphisms) for anxiety disorders and depression, our data showing that autoinhibition is not impaired in these mutants may provide a reference background for the interpretation of behavioral responses in these mice in the context of human psychopathology. For instance, functional autoinhibition in patients with depression were indirectly inferred from $5-\mathrm{HT}_{1 \mathrm{~A}}$ receptor imaging studies in the raphe (Drevets et al., 2007; Savitz et al., 2009). Overall, however, these studies failed to clarify whether the depression-related changes in $5-\mathrm{HT}_{1 \mathrm{~A}}$ receptor binding are genetically or environmentally driven during development, thus causative of the disorder, or whether they are simply an adaptation to acutely increased or decreased serotonergic transmission (Savitz et al., 2009).

Contradicting results were also gathered in the attempt to associate SERT polymorphisms with changes in the level of $5-\mathrm{HT}_{1 \mathrm{~A}}$ receptor expression/density. David et al. (2005) reported that carriers of the 5-HTTLPR s-allele had lower $5-\mathrm{HT}_{1 \mathrm{~A}}$ receptor binding potential in all the brain regions investigated compared to individuals homozygous for the l-allele. On the contrary, Lee et al. (2005) found that s-carriers had higher $5-\mathrm{HT}_{1 \mathrm{~A}}$ binding than $11-$ individuals in pregenual and subgenual cingulate cortex regions while in other regions, including the DRN, no difference was detected. More recently, Borg et al. (2009) could not reveal any differences in $5-\mathrm{HT}_{1 \mathrm{~A}}$ receptor density between carriers and noncarriers of the 5-HTTLPR s-allele and concluded that functional consequences of 5-HTTLPR are not likely to be mediated by differences in $5-\mathrm{HT}_{1 \mathrm{~A}}$ expression. Our results showing that 5 -HT system autoinhibition is not reduced in mice with impaired Sert function even in the presence of altered $5-\mathrm{HT}_{1 \mathrm{~A}}$ receptor sensitivity would support this conclusion.

A second implication of our results involves the possibility to infer the degree of 5-HT system autoinhibition from functional assays using activation of $5-\mathrm{HT}_{1 \mathrm{~A}}$ receptors with direct agonists, in patients or in animal models. For example, one of the most consistent findings among depressed patients is their blunted hypothermia in response to $5-\mathrm{HT}_{1 \mathrm{~A}}$ receptor direct agonists (Lesch et al., 1990; Lesch, 1991; Jacobsen et al., 2012b and references therein). Such responses are usually ascribed to desensitization of somatodendritic $5-\mathrm{HT}_{1 \mathrm{~A}}$ receptors (reviewed in Jacobsen et al., 2012a). Our data suggest that, whereas blunted hypothermic response to direct agonists is likely to reflect subsensitivity of 
$5-\mathrm{HT}_{1 \mathrm{~A}}$ receptors in these patients, this decrease in response cannot directly be correlated to functional consequences that entail reduced autoinhibition and increase in the basal firing rate of 5-HT neurons.

On the other hand, the finding that 5-HT neurons in Tph2and Sert-deficient mice display normal responsiveness to $\operatorname{Trp}$ and/or 5-HTP regarding autoinhibition of 5-HT neuron firing would support the use of $\operatorname{Trp}$ (or 5-HTP) as an appropriate challenge to test the functional state of 5-HT system in clinical settings and to reveal the involvement of altered autoinhibition in human psychopathology. Indeed, 5-HTP challenge has been successfully applied to reveal functional consequences dependent on 5-HTTLPR variation in humans (Maron et al., 2004).

Finally, the striking divergence between sensitivity to $\mathrm{R}(+)-8$ $\mathrm{OH}-\mathrm{DPAT}$ and 5-HT neuron autoinhibition in Sert-/- suggests the possibility that sustained increase in 5-HT levels by stressors or pharmacological treatments (e.g., SSRIs) may result in 5-HT $1 \mathrm{~A}$ receptor subsensitivity, not accompanied by functional impairment of 5-HT neuron firing autoregulation. For instance, the rapid decrease in 5- $\mathrm{HT}_{1 \mathrm{~A}}$ receptor sensitivity found in DRN 5-HT neurons following chronic ultramild stress and stressful uncontrolled environmental conditions is apparently not correlated with an increase in 5-HT system activity and has been suggested to be an adaptive mechanism to compensate for 5-HT fluctuations produced by stressful events (Laaris et al., 1999; Lanfumey et al., 1999). Interestingly, in vivo recording after chronic unpredictable stress in rats showed that the reduced ability of $8-\mathrm{OH}$-DPAT to inhibit 5-HT neuron firing was accompanied by a decrease in firing rate of DRN 5-HT neurons (Bambico et al., 2009), indicating that functional autoinhibition may be preserved in spite of $5-\mathrm{HT}_{1 \mathrm{~A}}$ receptor desensitization. Furthermore, desensitization of autoinhibitory 5 $\mathrm{HT}_{1 \mathrm{~A}}$ receptors occurring with chronic SSRI administration (Le Poul et al., 2000; Hensler, 2002; Castro et al., 2003) has been proposed as a mechanism for 5-HT neurons to escape the sustained autoinhibition produced by the increase in 5-HT in raphe nuclei by blockade of Sert and to represent an important step to achieve enhanced therapeutic effects of SSRIs (Artigas et al., 1996). On the other hand, Richardson-Jones et al. (2010) showed that desensitization of $5-\mathrm{HT}_{1 \mathrm{~A}}$ autoreceptors is not sufficient for antidepressants to convey their efficacy, indicating dissociation between desensitization of $5-\mathrm{HT}_{1 \mathrm{~A}}$ autoreceptors and behavioral effects of chronic SSRI treatment. Thus, desensitization of $5-\mathrm{HT}_{1 \mathrm{~A}}$ autoreceptors

\section{REFERENCES}

Albert, P. R. (2012). Transcriptional regulation of the 5-HT1A receptor: implications for mental illness. Philos. Trans. R. Soc. Lond. B Biol. Sci. 367, 2402-2415. doi: 10.1098/rstb. 2011.0376

Albert, P. R., and Francois, B. L. (2010). Modifying 5-HT1A receptor gene expression as a new target for antidepressant therapy. Front. Neurosci. 4:35. doi: 10.3389/fnins.2010. 00035

Alenina, N., Kikic, D., Todiras, M., Mosienko, V., Qadri, F., Plehm, R., et al. (2009). Growth retardation and altered autonomic control in mice

appears rather to be an adaptive mechanism to neutralize elevated extracellular 5-HT levels, and not a primary factor leading to behavioral alteration.

Under a functional perspective, however, dynamic changes in the sensitivity/expression of $5-\mathrm{HT}_{1 \mathrm{~A}}$ receptors appear to be crucial to fulfill the requirements for physiological homeostasis of 5-HT system functioning. Thus, any impairment of adaptive mechanisms of $5-\mathrm{HT}_{1 \mathrm{~A}}$ receptors in response to sustained changes in 5-HT levels, or constitutive alteration of their expression even in the absence of altered 5-HT levels in vivo, becomes a potential source of pathological consequences. In fact, genetically induced overexpression of somatodendritic $5-\mathrm{HT}_{1 \mathrm{~A}}$ receptors in mice has been shown to produce autonomic dysregulation (Audero et al., 2008), behavioral alterations, and decreased response to antidepressant drugs (RichardsonJones et al., 2010). In humans, the $\mathrm{C}(-1019) \mathrm{G} 5-\mathrm{HT}_{1 \mathrm{~A}}$ promoter polymorphism leading to $5-\mathrm{HT}_{1 \mathrm{~A}}$ receptor overexpression is proposed to represent a risk factor for depression (Lemonde et al., 2003; Strobel et al., 2003; Rothe et al., 2004; reviewed in Albert and Francois, 2010) and response to antidepressant drugs (reviewed in Albert, 2012).

In conclusion, our data reveal that 5-HT neuron autoinhibition is similar in all Tph2 and Sert genotypes studied, regardless of the different sensitivity of their somatodendritic $5-\mathrm{HT}_{1 \mathrm{~A}}$ receptors to $\mathrm{R}(+)-8-\mathrm{OH}$-DPAT. This suggests that adaptive changes in receptor sensitivity occur to compensate for variable extracellular 5-HT levels in different genotypes to homeostatically conserve autoinhibition in a physiological range. Thus, it appears that response to $5-\mathrm{HT}_{1 \mathrm{~A}}$ agonists per se is not always sufficient for evaluating the functional state of the 5-HT system, for which Trp and/or 5-HTP challenges may provide more informative data, both in clinical and animal experimental settings.

\section{ACKNOWLEDGMENTS}

Supported by the DFG (KFO 125, SFB TRR 58/A1 and A5), BMBF (IZKF Wuerzburg, 01KS9603), Compagnia di San Paolo (Programma Neuroscienze-2008.2265), and the EC (NEWMOOD LSHM-CT-2004-503474). Naozumi Araragi was supported by a grant of the German Excellence Initiative to the Graduate School of Life Sciences (GSLS), University of Wuerzburg. The article publishing fee was funded by the DFG and the University of Wuerzburg in the funding program Open Access Publishing.

depressed suicide victims. Neuropsychopharmacology 25, 892-903. doi: 10.1016/S0893-133X(01)00310-4

Artigas, F., Romero, L., De Montigny, C., and Blier, P. (1996). Acceleration of the effect of selected antidepressant drugs in major depression by 5 HT1A antagonists. Trends Neurosci. 19, 378-383. doi: 10.1016/S01662236(96) 10037-0

Audero, E., Coppi, E., Mlinar, B., Rossetti, T., Caprioli, A., Banchaabouchi, M. A., et al. (2008). Sporadic autonomic dysregulation and death associated with excessive serotonin autoinhibition. Science 321, 130-133. doi: 10.1126/science. 1157871
Bambico, F. R., Nguyen, N. T., and Gobbi, G. (2009). Decline in serotonergic firing activity and desensitization of 5-HT1A autoreceptors after chronic unpredictable stress. Eur. Neuropsychopharmacol. 19, 215228. doi: 10.1016/j.euroneuro. 2008. 11.005

Bengel, D., Murphy, D. L., Andrews, A. M., Wichems, C. H., Feltner, D., Heils, A., et al. (1998). Altered brain serotonin homeostasis and locomotor insensitivity to 3, 4methylenedioxymethamphetamine ("Ecstasy") in serotonin transporterdeficient mice. Mol. Pharmacol. 53, 649-655. 
Borg, J., Henningsson, S., Saijo, T., Inoue, M., Bah, J., Westberg, L., et al. (2009). Serotonin transporter genotype is associated with cognitive performance but not regional 5-HT1A receptor binding in humans. Int. J. Neuropsychopharmacol. 12, 783-792. doi: $10.1017 / \mathrm{S} 1461145708009759$

Bouali, S., Evrard, A., Chastanet, M., Lesch, K. P., Hamon, M., and Adrien, J. (2003). Sex hormone-dependent desensitization of 5-HT1A autoreceptors in knockout mice deficient in the 5-HT transporter. Eur. J. Neurosci. 18, 2203-2212. doi: 10.1046/j.14609568.2003.02960.x

Brown, R. E., Mckenna, J. T., Winston, S., Basheer, R., Yanagawa, Y., Thakkar, M. M., et al. (2008). Characterization of GABAergic neurons in rapid-eye-movement sleep controlling regions of the brainstem reticular formation in GAD67green fluorescent protein knock-in mice. Eur. J. Neurosci. 27, 352 363. doi: $10.1111 /$ j.1460-9568.2008. 06024.x

Canli, T., and Lesch, K. P. (2007). Long story short: the serotonin transporter in emotion regulation and social cognition. Nat. Neurosci. 10, 1103-1109. doi: 10.1038/nn1964

Carlsson, A., Davis, J. N., Kehr, W., Lindqvist, M., and Atack, C. V. (1972). Simultaneous measurement of tyrosine and tryptophan hydroxylase activities in brain in vivo using an inhibitor of the aromatic amino acid decarboxylase. Naunyn Schmiedebergs Arch. Pharmacol. 275, 153-168. doi: 10.1007/BF00508904

Castro, M., Diaz, A., Del Olmo, E., and Pazos, A. (2003). Chronic fluoxetine induces opposite changes in G protein coupling at pre and postsynaptic 5-HT1A receptors in rat brain. $\mathrm{Neu}$ ropharmacology 44, 93-101. doi: 10. 1016/S0028-3908(02)00340-4

Corradetti, R., Laaris, N., Hanoun, N., Laporte, A. M., Le Poul, E., Hamon, M., et al. (1998). Antagonist properties of (-)-pindolol and WAY 100635 at somatodendritic and postsynaptic 5-HT1A receptors in the rat brain. Br. J. Pharmacol. 123, 449-462. doi: 10.1038/sj.bjp.0701632

David, S. P., Murthy, N. V., Rabiner, E. A., Munafo, M. R., Johnstone, E. C. Jacob, R., et al. (2005). A functional genetic variation of the serotonin (5-HT) transporter affects 5-HT1A receptor binding in humans. J. Neurosci. 25, 2586-2590. doi: 10.1523/ JNEUROSCI.3769-04.2005

Drevets, W. C., Frank, E., Price, J. C., Kupfer, D. J., Holt, D., Greer, P. J., et al. (1999). PET imaging of serotonin $1 \mathrm{~A}$ receptor binding in depression.
Biol. Psychiatry 46, 1375-1387. doi: 10.1016/S0006-3223(99)00189-4

Drevets, W. C., Thase, M. E., MosesKolko, E. L., Price, J., Frank, E., Kupfer, D. J., et al. (2007). Serotonin$1 \mathrm{~A}$ receptor imaging in recurrent depression: replication and literature review. Nucl. Med. Biol. 34, 865877. doi: 10.1016/j.nucmedbio.2007. 06.008

Evans, A. K., Reinders, N., Ashford, K. A., Christie, I. N., Wakerley, J. B., and Lowry, C. A. (2008). Evidence for serotonin synthesis-dependent regulation of in vitro neuronal firing rates in the midbrain raphe complex. Eur. J. Pharmacol. 590, 136-149. doi: 10.1016/j.ejphar.2008.06.014

Fabre, V., Beaufour, C., Evrard, A., Rioux, A., Hanoun, N., Lesch, K. P., et al. (2000). Altered expression and functions of serotonin 5-HT1A and 5-HT1B receptors in knock-out mice lacking the 5-HT transporter. Eur. J. Neurosci. 12, 2299-2310. doi: 10.1046/j.1460-9568.2000.00126.x

Fox, M. A., Stein, A. R., French, H. T., and Murphy, D. L. (2010). Functional interactions between 5-HT2A and presynaptic 5-HT1A receptorbased responses in mice genetically deficient in the serotonin 5-HT transporter (SERT). Br. J. Pharmacol. 159, 879-887. doi: 10.1111/j.14765381.2009.00578.x

Gobbi, G., Murphy, D. L., Lesch, K., and Blier, P. (2001). Modifications of the serotonergic system in mice lacking serotonin transporters: an in vivo electrophysiological study. J. Pharmacol. Exp. Ther. 296, 987-995.

Gutknecht, L., Araragi, N., Merker, S., Waider, J., Sommerlandt, F. M., Mlinar, B., et al. (2012). Impacts of brain serotonin deficiency following Tph2 inactivation on development and raphe neuron serotonergic specification. PLOS ONE 7:e43157. doi: 10.1371/journal.pone. 0043157

Gutknecht, L., Jacob, C., Strobel, A., Kriegebaum, C., Muller, J., Zeng, Y., et al. (2007). Tryptophan hydroxylase-2 gene variation influences personality traits and disorders related to emotional dysregulation. Int. J. Neuropsychopharmacol. 10, 309-320. doi: $10.1017 /$ S1461145706007437

Gutknecht, L., Kriegebaum, C., Waider, J., Schmitt, A., and Lesch, K. P. (2009). Spatio-temporal expression of tryptophan hydroxylase isoforms in murine and human brain: convergent data from Tph2 knockout mice. Eur. Neuropsychopharmacol. 19 , 266-282. doi: 10.1016/j.euroneuro. 2008.12.005
Gutknecht, L., Waider, J., Kraft, S., Kriegebaum, C., Holtmann, B., Reif, A., et al. (2008). Deficiency of brain 5-HT synthesis but serotonergic neuron formation in Tph2 knockout mice. J. Neural. Transm. 115, 1127-1132. doi: 10.1007/ s00702-008-0096-6

Hensler, J. G. (2002). Differential regulation of 5-HT1A receptor-G protein interactions in brain following chronic antidepressant administration. Neuropsychopharmacology 26, 565-573. doi: 10.1016/S0893133X(01)00395-5

Jacobs, B. L., and Azmitia, E. C. (1992). Structure and function of the brain serotonin system. Physiol. Rev. 72, 165-229.

Jacobsen, J. P., Medvedev, I. O., and Caron, M. G. (2012a). The 5-HT deficiency theory of depression: perspectives from a naturalistic 5-HT deficiency model, the tryptophan hydroxylase $2 \mathrm{Arg} 439 \mathrm{His}$ knock in mouse. Philos. Trans. R. Soc. Lond. B Biol. Sci. 367, 2444-2459. doi: 10.1098/rstb.2012.0109

Jacobsen, J. P., Siesser, W. B., Sachs, B. D., Peterson, S., Cools, M. J. Setola, V., et al. (2012b). Deficient serotonin neurotransmission and depression-like serotonin biomarker alterations in tryptophan hydroxylase 2 (Tph2) loss-of-function mice. Mol. Psychiatry 17, 694-704. doi: 10.1038/mp. 2011.50

Laaris, N., Le Poul, E., Laporte, A. M., Hamon, M., and Lanfumey, L. (1999). Differential effects of stress on presynaptic and postsynaptic 5hydroxytryptamine-1A receptors in the rat brain: an in vitro electrophysiological study. Neuroscience 91, 947-958. doi: 10.1016/S03064522(98)00674-5

Lanfumey, L., Mannoury La Cour, C., Froger, N., and Hamon, M. (2000). 5-HT-HPA interactions in two models of transgenic mice relevant to major depression. Neurochem. Res. 25, 1199-1206. doi: 10.1023/A:1007683810230

Lanfumey, L., Pardon, M. C., Laaris, N., Joubert, C., Hanoun, N., Hamon, M., et al. (1999). 5-HT1A autoreceptor desensitization by chronic ultramild stress in mice. Neuroreport 10, 3369-3374. doi: 10.1097/00001756199911080-00021

Lee, M., Bailer, U. F., Frank, G. K., Henry, S. E., Meltzer, C. C., Price, J. C., et al. (2005). Relationship of a 5-HT transporter functional polymorphism to 5-HT1A receptor binding in healthy women. Mol. Psychiatry 10, 715-716. doi: 10 1038/sj.mp.4001680
Lemonde, S., Turecki, G., Bakish, D., Du, L., Hrdina, P. D., Bown, C. D., et al. (2003). Impaired repression at a 5-hydroxytryptamine $1 \mathrm{~A}$ receptor gene polymorphism associated with major depression and suicide. J. Neurosci. 23, 8788-8799.

Le Poul, E., Boni, C., Hanoun, N., Laporte, A. M., Laaris, N., Chauveau, J., et al. (2000). Differential adaptation of brain 5-HT1A and 5-HT1B receptors and 5-HT transporter in rats treated chronically with fluoxetine. Neuropharmacology 39, 110-122. doi: 10.1016/S00283908(99)00088-X

Lesch, K. P. (1991). 5-HT1A receptor responsivity in anxiety disorders and depression. Prog. Neuropsychopharmacol. Biol. Psychiatry 15, 723-733. doi: 10.1016/02785846(91)90001-H

Lesch, K. P., Araragi, N., Waider, J., Van Den Hove, D., and Gutknecht, L. (2012). Targeting brain serotonin synthesis: insights into neurodevelopmental disorders with long-term outcomes related to negative emotionality, aggression and antisocial behaviour. Philos. Trans. R. Soc. Lond. B Biol. Sci. 367, 2426-2443. doi: 10.1098/rstb.2012.0039

Lesch, K. P., Mayer, S., DisselkampTietze, J., Hoh, A., Schoellnhammer, G., and Schulte, H. M. (1990). Subsensitivity of the 5hydroxytryptamine1A (5-HT1A) receptor-mediated hypothermic response to ipsapirone in unipolar depression. Life Sci. 46, 1271-1277. doi: 10.1016/0024-3205(90)90359-Y

Levine, E. S., and Jacobs, B. L. (1992). Neurochemical afferents controlling the activity of serotonergic neurons in the dorsal raphe nucleus: microiontophoretic studies in the awake cat. J. Neurosci. 12, 4037-4044.

Li, Q., Wichems, C. H., Ma, L., Van De Kar, L. D., Garcia, F., and Murphy, D. L. (2003). Brain regionspecific alterations of 5-HT2A and 5 -HT2C receptors in serotonin transporter knockout mice. J. Neurochem. 84, 1256-1265. doi: 10.1046/j.14714159.2003.01607.x

Liu, R. J., Lambe, E. K., and Aghajanian, G. K. (2005). Somatodendritic autoreceptor regulation of serotonergic neurons: dependence on L-tryptophan and tryptophan hydroxylase-activating kinases. Eur. J. Neurosci. 21, 945-958. doi: 10.1111/j.1460-9568.2005.03930.x

Mannoury la Cour, C., Boni, C., Hanoun, N., Lesch, K. P., Hamon, M., and Lanfumey, L. (2001). Functional consequences of 5-HT 
transporter gene disruption on 5$\mathrm{HT}$ (1a) receptor-mediated regulation of dorsal raphe and hippocampal cell activity. J. Neurosci. 21, 21782185.

Maron, E., Tasa, G., Toru, I., Lang, A., Vasar, V., and Shlik, J. (2004). Association between serotonin-related genetic polymorphisms and CCK-4induced panic attacks with or without 5-hydroxytryptophan pretreatment in healthy volunteers. World J. Biol. Psychiatry 5, 149-154. doi: 10.1080/ 15622970410029927

Mathews, T. A., Fedele, D. E., Coppelli, F. M., Avila, A. M., Murphy, D. L., and Andrews, A. M. (2004). Gene dosedependent alterations in extraneuronal serotonin but not dopamine in mice with reduced serotonin transporter expression. J. Neurosci. Methods 140, 169-181. doi: 10.1016/j. jneumeth.2004.05.017

Meltzer, C. C., Price, J. C., Mathis, C. A., Butters, M. A., Ziolko, S. K., Moses-Kolko, E., et al. (2004). Serotonin 1A receptor binding and treatment response in late-life depression. Neuropsychopharmacology 29, 2258-2265. doi: 10.1038/sj. npp. 1300556

Mlinar, B., Tatini, F., Ballini, C., Nencioni, S., Della Corte, L., and Corradetti, R. (2005). Differential autoinhibition of 5hydroxytryptamine neurons by 5 hydroxytryptamine in the dorsal raphe nucleus. Neuroreport 16, 1351-1355. doi: 10.1097/01.wnr. 0000175249.25535.bf

Mosienko, V., Bert, B., Beis, D., Matthes, S., Fink, H., Bader, M., et al. (2012). Exaggerated aggression and decreased anxiety in mice deficient in brain serotonin. Transl. Psychiatry 2, e122. doi: 10.1038/tp. 2012.44

Murphy, D. L., and Lesch, K. P. (2008). Targeting the murine serotonin transporter: insights into human neurobiology. Nat. Rev. Neurosci. 9, 85-96. doi: 10.1038/ nrn2284

Neumeister, A., Bain, E., Nugent, A. C., Carson, R. E., Bonne, O., Luckenbaugh, D. A., et al. (2004). Reduced serotonin type $1 \mathrm{~A}$ receptor binding in panic disorder. J. Neurosci. 24, 589591. doi: 10.1523/JNEUROSCI.492103.2004

Parsey, R. V., Oquendo, M. A., Ogden, R. T., Olvet, D. M., Simpson, N., Huang, Y. Y., et al. (2006). Altered serotonin $1 \mathrm{~A}$ binding in major depression: a [carbonyl-C11]WAY100635 positron emission tomography study. Biol. Psychiatry 59, 106-113. doi: 10.1016/j.biopsych. 2005.06.016

Pineyro, G., and Blier, P. (1999). Autoregulation of serotonin neurons: role in antidepressant drug action. Pharmacol. Rev. 51, 533-591.

Qu, Y., Villacreses, N., Murphy, D L., and Rapoport, S. I. (2005). 5-HT2A/2C receptor signaling via phospholipase A2 and arachidonic acid is attenuated in mice lacking the serotonin reuptake transporter. Psychopharmacology (Berl.) 180, 12-20. doi: 10.1007/s00213-0052231-5

Richardson-Jones, J. W., Craige, C. P., Guiard, B. P., Stephen, A., Metzger, K. L., Kung, H. F., et al. (2010). 5HT1A autoreceptor levels determine vulnerability to stress and response to antidepressants. Neuron 65, 4052. doi: 10.1016/j.neuron.2009. 12.003

Rioux, A., Fabre, V., Lesch, K. P., Moessner, R., Murphy, D. L., Lanfumey, L., et al. (1999). Adaptive changes of serotonin 5-HT2A receptors in mice lacking the serotonin transporter. Neurosci. Lett. 262, 113 116. doi: 10.1016/S0304-3940(99) 00049-X

Rothe, C., Gutknecht, L., Freitag, C., Tauber, R., Mossner, R., Franke, P., etal. (2004). Association of a functional 1019C > G 5-HT1A receptor gene polymorphism with panic disorder with agoraphobia. Int. J. Neuropsychopharmacol. 7, 189-192. doi: 10.1017/S1461145703 004061

Sargent, P. A., Kjaer, K. H., Bench, C. J. Rabiner, E. A., Messa, C., Meyer, J., et al. (2000). Brain serotoninlA receptor binding measured by positron emission tomography with [11C]WAY-100635: effects of depression and antidepressant treatment. Arch. Gen. Psychiatry 57, 174-180. doi: 10.1001/archpsyc. 57.2.174

Savelieva, K. V., Zhao, S., Pogorelov, V. M., Rajan, I., Yang, Q., Cullinan, E., et al. (2008). Genetic disruption of both tryptophan hydroxylase genes dramatically reduces serotonin and affects behavior in models sensitive to antidepressants. PLOS ONE 3:e3301. doi: 10.1371/journal.pone. 0003301

Savitz, J., Lucki, I., and Drevets, W. C. (2009). 5-HT(1A) receptor function in major depressive disorder. Prog. Neurobiol. 88, $17-$ 31. doi: 10.1016/j.pneurobio.2009. 01.009

Sharp, T., Boothman, L., Raley, J., and Queree, P. (2007). Important messages in the 'post': recent discoveries in 5-HT neurone feedback control. Trends Pharmacol. Sci. 28, 629-636. doi: 10.1016/j.tips.2007.10.009

Shen, H. W., Hagino, Y., Kobayashi, H., Shinohara-Tanaka, K., Ikeda, K., Yamamoto, H., et al. (2004). Regional differences in extracellular dopamine and serotonin assessed by in vivo microdialysis in mice lacking dopamine and/or serotonin transporters. Neuropsychopharmacology 29, 1790-1799. doi: 10.1038/sj.npp. 1300476

Stockmeier, C. A., Shapiro, L. A., Dilley, G. E., Kolli, T. N., Friedman, L., and Rajkowska, G. (1998). Increase in serotonin-1A autoreceptors in the midbrain of suicide victims with major depression-postmortem evidence for decreased serotonin activity. J. Neurosci. 18, 73947401.

Strobel, A., Gutknecht, L., Rothe, C., Reif, A., Mossner, R., Zeng, Y., et al. (2003). Allelic variation in 5-HT1A receptor expression is associated with anxiety- and depression-related personality traits. J. Neural. Transm. 110, 1445-1453. doi: 10.1007/s00702 003-0072-0

Trulson, M. E., and Jacobs, B. L. (1979). Raphe unit activity in freely moving cats: correlation with level of behavioral arousal. Brain Res. 163, 135-150. doi: 10.1016/0006-8993 (79)90157-4

Vandermaelen, C. P., and Aghajanian, G. K. (1983). Electrophysiological and pharmacological characterization of serotonergic dorsal raphe neurons recorded extracellularly and intracellularly in rat brain slices. Brain Res. 289, 109-119. doi: 10.1016/00068993(83)90011-2

Willins, D. L., and Meltzer, H. Y. (1997). Direct injection of 5-HT2A receptor agonists into the medial prefrontal cortex produces a head-twitch response in rats. J. Pharmacol. Exp. Ther. 282, 699-706.

Conflict of Interest Statement: The authors declare that the research was conducted in the absence of any commercial or financial relationships that could be construed as a potential conflict of interest.

Received: 06 March 2013; paper pending published: 12 June 2013; accepted: 17 July 2013; published online: 02 August 2013.

Citation: Araragi N, Mlinar B, Baccini G, Gutknecht L, Lesch K-P and Corradetti $R$ (2013) Conservation of 5-HT1A receptor-mediated autoinhibition of serotonin (5-HT) neurons in mice with altered 5-HT homeostasis. Front. Pharmacol. 4:97. doi: 10.3389/ fphar.2013.00097

This article was submitted to Frontiers in Neuropharmacology, a specialty of Frontiers in Pharmacology. Copyright: (C) 2013 Araragi, Mlinar, Baccini, Gutknecht, Lesch and Corradetti. This is an open-access article distributed under the terms of the Creative Commons Attribution License (CC BY). The use, distribution or reproduction in other forums is permitted, provided the original author(s) or licensor are credited and that the original publication in this journal is cited, in accordance with accepted academic practice. No use, distribution or reproduction is permitted which does not comply with these terms. 